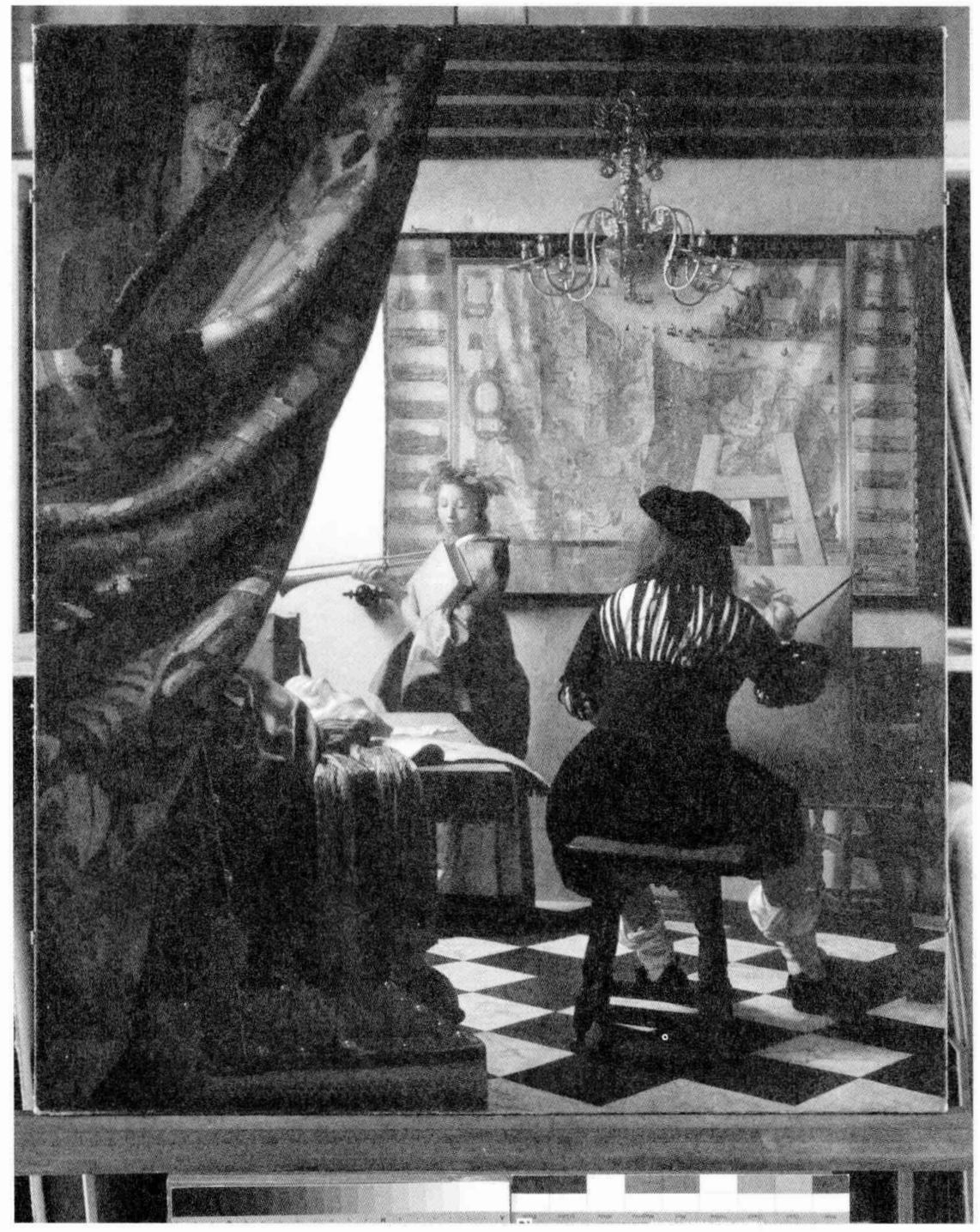




\section{Lyon Ratbbun}

Profesor asistente en la Universidad de Texas en Brownsville. Tiene un máster en historia por la Universidad Estatal de San Francisco y un doctorado en retórica por la Universidad de California en Berkeley. Se interesa en las relaciones históricas entre Estados Unidos y México y es autor de "Reassessing William Prescott's History of the Conquest of Mexico as Literary History", Prose Studies, 2003; "Champions of Mexico in Ante-Bellum America", Journal of Popular Culture, vol. 35.2 (otoño de 2001); "The Debate over Annexing Texas and the Emergence of Manifest Destiny", Rhetoric and Public Affairs (otoño de 2001), y "The Ciceronian Rhetoric of John Quincy Adams", Rhetorica (primavera de 2000).

\section{Resumen}

En este artículo se analiza la actitud cambiante frente a México de John Quincy Adams, de ser el primer arquitecto de la expansión territorial de Estados Unidos en la época nacional temprana hasta convertirse en ardiente defensor de la integridad territorial de México en los años treinta. El autor se plantea también la siguiente pregunta: ¿Qué nos dice la transformación de John Quincy Adams sobre las relaciones más amplias entre Estados Unidos y México? El trabajo muestra cómo, durante la segunda década del siglo XIX, en la búsqueda de autosuficiencia y ampliación territorial de Estados Unidos, Adams valoraba poco el potencial cívico de México y estaba ansioso por adquirir Texas y otros territorios mexicanos. Con su derrota en las elecciones de 1828 , se convirtió en opositor de la expansión jacksoniana. Al resistir la expansión de la esclavitud -y la posibilidad de que la república se convirtiera en un imperio conquistadorAdams se vio obligado, a pesar suyo, a defender la integridad de México.

Palabras clave:

Relaciones México-Estados Unidos, expansionismo estadunidense, Texas, esclavitud, John Quincy Adams, Andrew Jackson.

\section{Abstract}

This paper analyzes John Quincy Adams' changing attitude to Mexico, from being the leading architect of American territorial expansion in the early nationalist period to an ardent defender of Mexico's territorial integrity during the 1830s. The author is also concerned with the following question: What does John Quincy Adams' transformation tell us about the broader relationship between the United States and Mexico? The article shows how, during the 1810 s, in seeking to expand the economic selfsufficiency and territorial extent of the United States, Adams had ignored Mexico's civic potential and was eager to acquire Texas and other Mexican territories. Following his defeat in the 1828 elections, he became an opponent of Jacksonian expansion. In resisting the expansion of slavery -and the possibility of the republic becoming a conquering empire-Adams was compelled, despite himself, to defend the integrity of Mexico.

\section{Key words:}

US-Mexican relations, American exjansionism, Texas, slavery, John Quincy Adams, Andrew Jackson.

Fecha de recepción: junio de 2003

Fecha de aceptación: junio de 2004 


\title{
La transformación de la visión de John Quincy Adams sobre México*
}

\author{
Lyon Ratbbun
}

$\mathrm{E}$ 128 de noviembre de 1843 , John Quincy Adams escribió en su diario que Juan N. Almonte, el ministro de México ante Estados Unidos, le había hecho una visita oficial "parà rendirle el agradecimiento del gobierno mexicano y de la nación por la amabilidad y generosidad de mi conducta hacia México, tanto en el Congreso de Estados Unidos como en las reuniones con la gente". ${ }^{1} \mathrm{Al}$ oponerse a la anexión de Texas a Estados Unidos, John Quincy Adams se había convertido en el más celoso adalid de México dentro del gobierno federal de Estados Unidos.

El saludo de Juan Almonte a Adams era profundamente irónico: hasta antes de ser derrotado por Andrew Jackson en la elección presidencial de 1828 , John Quincy Adams había sido el primer arquitecto de la expansión territorial estadu-

* Traducción de Gabriela Montes de Oca Vega. Título original "The Transformation of John Quincy Adams' View of Mexico".

${ }^{1}$ Adams, Memoirs, 1874-1877, p. 176. Aparentemente Adams no tenía conocimiento de que Almonte era el hijo ilegírimo del gran héroe revolucionario de México, José María Morelos, y que había entablado amistad con el aliado de Adams, Benjamin Lundy, durante los viajes de éste a Texas. Las biografías más recientes de Adams son: Remini, Jobn, 2002; Lewis, Jobn, 2001; Nagel, Jobn, 1997. nidense. A lo largo de este periodo, había ayudado a popularizar la ética nacionalista - conocida en la década de 1840 como Destino Manifiesto- que justificaría la apropiación de las provincias del norte de México. ¿Cómo llegó el principal expansionista del primer periodo nacionalista a defender la soberanía de México de manera tan ardiente durante el decenio de 1830? ¿Qué nos dice la transformación de John Quincy Adams sobre el conjunto de la relación más amplia entre Estados Unidos y México?

\section{ADAMS Y MÉXICO DURANTE EL PRIMER PERIODO NACIONALISTA}

De manera significativa, durante la larga guerra de independencia de México, muchos estadunidenses influyentes solicitaron al gobierno de Estados Unidos que ayudara a México a independizarse de España. En 1810, el mismo año en que estalló la revolución en México, Zebulon Pike publicó Southwestern Expedition, que retrataba sus viajes por las provincias norteñas de México. Dado que Pike consideraba a los habitantes europeizados de México como iguales cívicos de los estadunidenses, imploraba a sus conciudadanos que auxiliaran a este país en su lucha de independencia contra España. "Veinte 
mil auxiliares de Estados Unidos", escribió Pike, "unidos a los independentistas del país, son en todo momento suficientes para crear y producir la revolución". ${ }^{2}$ Pike nunca sugirió que el pueblo o los territorios mexicanos debieran absorberse a la república estadunidense en expansión. Pike concluía su relato sin ambigüedades, afirmando que México debería adquirir la soberanía política y convertirse en un vecino de Estados Unidos en igualdad de condiciones.

En el decenio de 1810, muchos estadunidenses hicieron suya la solicitud de Zebulon Pike de ayudar a México en su lucha por la independencia. Escritores como William Shaler, Henry Marie Brackenridge, William Robinson, William Duane y Hezekiah Niles representaban a los mexicanos como personas cívicas luchando por crear una república independiente a la imagen de Estados Unidos. Henry Clay expresaba una opinión muy difundida cuando declaró en la Cámara de Representantes en 1818 que

Los caballeros cometerán un craso error si forman su opinión sobre la actual situación moral de Hispanoamérica a partir de lo que solía ser bajo el degradante sistema español. Es emplazar las disposiciones de la propia Providencia suponer que ha creado seres incapaces de gobernarse y ser pisoteados por: reyes. El autogobierno es el gobierno natural del hombre. ${ }^{3}$

Adoptando la fe de Clay en que los antiguos súbditos de las colonias españolas podrían convertirse en ciudadanos de sus propias repúblicas, Hezekiah Niles

\footnotetext{
${ }^{2}$ Pike, Expeditions, 1895, t. 3, p. 50.

${ }^{3}$ Clay, Works, 1904, t. 1, p. 245.
}

escribió editoriales apasionados en su popular semanario Weekly Register, que buscaba definir la relevancia de la revolución mexicana para los estadunidenses. Niles explicó en un pronunciamiento típico:

Los iguales se atraen naturalmente, y si en verdad amamos a la república de Norteamérica, ¿podemos ser indiferentes ante el establecimiento de una república en el sur del continente, una hermana, de la cual podemos albergar las mejores predicciones? ${ }^{-1}$

De manera similar, Henry Marie Brackenridge sostuvo en su panfleto de 1814, Views from Louisiana, que un México independiente evitaría que el territorio de Estados Unidos se extendiese demasiado y ofrecería un mercado valioso para los productos estadunidenses.

\section{¿Podrían estas personas independizarse y regenerarse mediante el espíritu ennoblece- dor de la libertad? _escribió Brackenridge-, el continente del Norte sería posesión ex- clusiva de dos grandes naciones, los esta- dunidenses y los mexicanos, unidos en la amistad por intereses armónicos y la sim- patía de los gobiernos. ${ }^{5}$}

Mientras Henry Clay, Hezekiah Niles, Hugh Breckenridge y otros convocaban a sus conciudadanos a ayudar a México, y a otras colonias españolas, John Quincy Adams estaba interesado -exclusivamente- en promover la grandeza nacional de Estados Unidos. Adams había sido el único federalista del Senado que aprobó la adquisición de Luisiana por Jefferson. Como uno de los negociadores en Ghent

\footnotetext{
${ }^{4}$ Weekly Register, sábado 7 de junio de 181.7.

5 Brackenridge, "Views", 1904, t. 6, p. 163.
} 
en 1814, protegió enérgicamente los derechos de pesca de Estados Unidos en Terranova y Labrador al tiempo que se oponía a cualquier discriminación en contra de las mercancías, o los derechos marítimos de Estados Unidos. Como ministro plenipotenciario en Gran Bretaña entre 1815 y 1817 , Adams contribuyó a trazar la frontera entre Estados Unidos y Canadá entre los Grandes Lagos y las Montañas Rocosas a lo largo del paralelo 49. Gran Bretaña había insistido en que se trazara la línea 150 millas más al sur para otorgar a los comerciantes británicos acceso directo al río Mississippi. Debido a que evitó esto, Adams logró que Estados Unidos conservara grandes secciones de los estados actuales de Minnesota, Dakota del Norte, Montana y Washington. Como secretario de Estado se proponía ampliar los derechos comerciales de Estados Unidos en las Indias Occidentales de Gran Bretaña, abolir la piratería y establecer los derechos del comercio neutral en periodo de guerra. Los esfuerzos vigorosos de Adams por ampliar el control estadunidense en el continente culminaron en el Tratado Transcontinental de 1819, que convirtió a Estados Unidos en una república continental por primera vez. Su triunfo al negociar el Tratado de 1819 fue coronado por la formulación que el mismo Adams hizo de la Doctrina Monroe y, por último, por su elección a la presidencia en $1824 .^{6}$

Cuando promovía la expansión territorial de Estados Unidos, Adams también estaba declarando que Estados Unidos poseía un destino providencial para extenderse a lo largo del continente. En su "Oración pronunciada en Plymouth" de
1802, que fue ampliamente difundicla, Adams explicaba que las virtudes encarnadas en los colonizadores puritanos de la colonia de Plymouth asegurarían la futura gloria de la nación. "Preservar en toda su pureza aquellas virtudes que en este clía conmemoramos" anunció Adams "y ustedes habrán de encumbrarse en un vuelo veloz y constante a la cima de la gloria humana". Lanzándose hacia una conclusión plena de pasión, Adams declaró:

Hace casi un siglo, una de esas mentes singulares a quienes les ha sido dado discernir la grandeza futura desde sus principios bási$\cos$, al contemplar la situación de este continente pronunció con vena de inspiración poética "La estrella del imperio emprende su ruta hacia el occidente." Unámonos todos en súplicas ardientes con el fundador de naciones y constructor de mundos para que lo que antes fue profecía pueda continuar desarrollándose como historia, que las esperanzas más caras para la raza humana no se extingan en la desilusión y que el último imperio demuestre ser el más noble de todos. ${ }^{7}$

Las resonantes frases de la conclusión de Adams se basaban en una lógica con tono yanqui de un destino manifiesto: en el pasado Dios había favorecido a Estados Unidos porque los puritanos de Nueva Inglaterra habían sido virtuosos; Dios protegería a la república en el futuro si sus ciudadanos continuaban practicando las virtudes que caracterizaron a los primeros pobladores de la colonia Plymouth. Mientras progresaba su carrera, y la nación ingresaba en un periodo de crecimiento sin paralelo después de la guerra de 1812 , Adams se fue convenciendo cada vez más

\footnotetext{
7 Adams, "Oration", 1802, p. 31.
}

${ }^{6}$ Adams, John, 1965, pp. 13-27. 
de la virtud colectiva de su país. Redobló sus esfuerzos diplomáticos por promover la expansión y fue aumentando la intensidad que imprimía a sus elegías retóricas para el imperio americano.

Tal vez la oración más jingoísta que Adams pronunció durante su ascenso a la presidencia fue "Alocución pronunciada en ocasión de la lectura de la Declaración de Independencia del 4 de julio de 1821". Su sarcástica censura de Inglaterra fue denunciada en la prensa británica, le otorgó a Adams gran notoriedad en las primeras escaramuzas de la elección presidencial de 1824 y enunció con energía la emergente ideología de la nación como imperio. Adams anunció proféticamente que la Declaración de Independencia "era la piedra angular de un nuevo tejido destinado a cubrir toda la superficie del globo". Estados Unidos, declaraba, eclipsaría la grandeza del Imperio Británico al cumplir su destino providencial. Comparando a Estados Unidos con Gran Bretaña, Adams declaró además:

No es mediante la maquinación de agentes de la destrucción que Estados Unidos desea dedicar su genio inventivo a la admiración o gratitud de la posteridad; tampoco es en la detección de los secretos ni en la composición de una nueva modificación de la naturaleza física. Ni siquiera es su propósito alcanzar la gloria de la ambición romana. Su gloria no es la dominación, sino la libertad. Su progreso es el avance de la mente. Tiene lanza y escudo: pero el lema estampado en su escudo es Libertad, Independencia, Paz. Esto ha sido su declaración; esto ha sido, hasta donde lo permitiera su relación con el resto de la humanidad, su práctica. ${ }^{8}$

" Adams, "Address", 1821, p. 31.
$\mathrm{Al}$ aumentar su propia popularidad a través de su vehemente denuncia de Gran Bretaña, Adams había reunido todos los temas clave del Destino Manifiesto: había descrito a Estados Unidos singularmente virtuoso y exento de la corrupción que degradaba a Gran Bretaña y a otras sociedades europeas. De cumplir la voluntad divina, Estados Unidos permanecería libre de todo reproche, ipso facto, en su avance por su propia ruta occidental hacia el imperio. El discurso indicaba que John Quincy Adams estaba listo para asumir el mando de la nación que, finalmente, estaba preparada para reclamar un futuro.

Cuando promovía el destino providencial de la nación como orador, y la expansión territorial como diplomático, John Quincy Adams nunca apoyaba la revolución mexicana en contra del dominio español. A lo largo de la década de 1810 , mientras otros solicitaban la ayuda de Estados Unidos para la guerra de independencia mexicana, Adams defendía la política oficial de la neutralidad. Desde la administración de George Washington la neutralidad había minimizado el involucramiento en rivalidades europeas, al tiempo que aumentaba al máximo las oportunidades de comercio con todos los participantes de las guerras precipitadas por la revolución francesa. Ni la administración de Jefferson ni la de Madison o la de Monroe se atrevían a poner en peligro los beneficios probados de la neutralidad a cambio de la inseguridad de ayudar a gobiernos patriotas inestables. En sus instrucciones de 1819 a "agentes para Sudamérica", Monroe reflejaba la decisión defensiva que conformaba la política estadunidense hacia América Latina en su conjunto. 
Si las hubiésemos reconocido [escribía Monroe en referencia a las colonias españolas] hay muchas razones para creer que habríamos ofendido otros poderes y habríamos provocado en éstos una disposición para contraatacar su efecto probable.?

Ayudar a los movimientos revolucionarios de América Latina podría encender una nueva guerra e interrumpir la fantástica aceleración del crecimiento económico que se había iniciado en 1815 .

Aunque vender excedentes de alimentos en mercados extranjeros había formado parte de la visión agraria de los republicanos jeffersonianos, la revolución del mercado impulsada por republicanos nacionales al finalizar la guerra de 1812 estaba creando una economía autosuficiente. Mediante el desarrollo integral de la agricultura, la manufactura y el comercio, alimentado por el incremento de la expansión por el continente, el país se volvería económicamente autosuficiente. ${ }^{10}$ Como explicaba Hezekiah Niles en un editorial de 1817 en el Weekly Register, la agricultura, la manufactura y el comercio eran necesarios para la prosperidad de la nación. "Los tres", escribía Niles, "en ciertas proporciones justas, deben existir para crear y mantenernos como un pueblo libre, feliz y próspero". ${ }^{11} \mathrm{Al}$ crecer su economía, los estadunidenses tendían cada vez más a identificar "el sistema americano" exclusivamente con la expansión de la economía, no con la apertura de nuevos mercados en las repúblicas emergentes de América Latina. Durante la década de

\footnotetext{
${ }^{9}$ Monroe, Writings, 1902, t. 6, p. 95.

${ }^{10}$ Watts, Republic, 1987, pp. 209-274.

${ }^{11}$ Weekly Register, sábado 7 de junio de 1817.
}

1810 no hubo dirigente republicano alguno que propusiera esta posición con más ímpetu polémico que John Quincy Adams.

Para John Quincy Adams la idea de que Sudamérica podría ser parte de un "sistema americano" hemisférico era descabellada. "En cuanto a un sistema americano", escribió en su diario en 1820, "lo tenemos; nosotros constituimos su totalidad; no hay comunidad de intereses ni de principios entre América del Norte y del Sur". ${ }^{12}$ John Quincy Adams no veía ninguna identidad, de ningún tipo, entre la revolución americana y los levantamientos sociales que tenían lugar en México y el resto de América Latina. "Nuestra independencia", escribió Adams "se declaró en defensa de nuestras libertades, y el intento de hacer del yugo de la dependencia un yugo de opresión fue la causa y la justificación de su inicio". En contraste, las colonias españolas habían respondido con una anarquía cacofónica a la fractura del poder imperial. " $\mathrm{La}$ independencia de las colonias españolas", afirmaba Adams, "les fue impuesta primero por el sometimiento temporal de la propia España a una potencia extranjera". ${ }^{13}$ Para Adams, las revoluciones de América Latina eran confusos accidentes de la historia, no reclamos deliberados de libertad política.

En opinión de Adams, la división cultural entre América del Norte y del Sur era tan profunda como el abismo entre Estados Unidos y las monarquías de Europa. Meditando sobre una discusión reciente con Henry Clay, John Quincy Adams escribió en su diario:

\footnotetext{
12 Adams, Memoirs, 1969, t. 5, p. 176.

${ }^{13}$ Adams, Selected, 1946, p. 345.
} 
Sin embargo no veo ninguna perspectiva de que ellos [los sudamericanos] establezcan instituciones de gobierno libres o liberales. El poder arbitrario, tanto militar como eclesiástico, estaba estampado en su educación, en sus hábitos y en todas sus instituciones. ${ }^{14}$

John Quincy Adams no veía ningún prospecto para que México, o cualquier otra colonia española, emergiera como república hermana de Estados Unidos. Para este destacado arquitecto de la expansión territorial, Estados Unidos era el único coto de la libertad política en el continente americano.

Cuando estadunidenses como Henry Clay y Hezekiah Niles llamaron a sus conciudadanos a renovar su virtud cívica colectiva ayudando a México a convertirse en una república independiente, John Quincy Adams y otros nacionalistas expresaron un profundo escepticismo con respecto al potencial cívico de las antiguas colonias españolas. De manera creciente identificaban la libertad cívica como propiedad exclusiva de Estados Unidos en rápida expansión. Sin embargo, las profundas divisiones sobre la esclavitud, entremezcladas con un creciente desacuerdo sobre Texas, empezaron a complicar el paisaje político en el decenio de 1829. En un ambiente político alterado, John Quincy Adams surgiría como el principal oponente de la expansión territorial a través de las provincias del norte de México y como el más activo defensor estadunidense de la integridad geográfica y cívica de México.

\footnotetext{
${ }^{14}$ lbid., p. 319.
}

\section{LAS DIFERENCIAS SOBRE TEXAS} Y LA ESCLAVITUD EN 1820

Si bien el Tratado Transcontinental de 1819 ratificaba la soberanía estadunidense sobre Florida, también había renunciado a todo reclamo de Estados Unidos sobre los territorios sudoccidentales al oeste del río Sabine, una medida que amenazaba profundamente a muchos sureños. Aunque el tratado de 1819 bloqueaba la expansión sureña hacia el suroeste, el Convenio de 1820 excluía la esclavitud al norte de la latitud $36^{\circ} 30^{\prime}$, la frontera del sur de Missouri. Muchos sureños reaccionaron sintiéndose profundamente engañados. ${ }^{15}$ Antes de 1820, John Calhoun, Andrew Jackson y John Quincy Adams habían adoptado la visión de Jefferson del Imperio de la Libertad que se extendía a lo largo del continente "duplicando las cifras de la humanidad, y desde luego la cantidad de existencia y felicidad". ${ }^{16}$ Después de que se fraguó el convenio de Missouri y de que se ratificó el Tratado Transcontinental, estos tres dirigentes nacionales empezaron a desarrollar sus ideas mutuamente antagónicas acerca del futuro de la nación. Había diferencias muy arraigadas sobre Texas que fueron decisivas para acabar con el consenso que había unido a los republicanos a raíz de la guerra de 1812.

El Tratado Adams-Onís se había negociado en torno de una fórmula sencilla: por una parte, las demandas estadunidenses sobre el río Columbia y la costa del Pacífico quedarían salvaguardadas y la

${ }^{15}$ Freehling, Road, 1990, p. 23.

16 Jefferson, "Observations", 1950, t. 10, p. 310. 
neutralidad estadunidense en el conflicto colonial español permanecería intacta. Por otra parte, Estados Unidos renunciaría a todo reclamo territorial al oeste del río Sabine, mientras que España abandonaría sus exigencias al este del Mississippi. ${ }^{17}$ En esa época, Adams creía que abandonar el cuestionable reclamo del país por el sudoeste sería temporal. Las propias adquisiciones territoriales ganadas mediante el tratado, aseguraba Adams al gabinete en noviembre de 1819, "hacían aún más inevitable que al final el resto del continente deberá pertenecernos". ${ }^{18}$

Con miras a hacer realidad su visión de la expansión continental como presidente, el propio Adams intentó comprar Texas a México. Sin embargo, el estancamiento en admitir a Missouri como un estado libre le había hecho temer que agregar territorio a la Unión pudiera aumentar el poder del Sur en el gobierno nacional. La visión de Adams del progreso nacional había supuesto que la esclavitud desaparecería gradualmente en el Sur, como había ocurrido en el Norte después de la guerra revolucionaria. ${ }^{19}$ No obstante, la crisis de Missouri había demostrado que los sureños estaban decididos a proteger la esclavitud, incluso al costo de separarse de la Unión. ${ }^{20}$ En la época del Convenio de Missouri, Adams se preguntaba en su diario si los del Norte no deberían haber resistido con respecto a la esclavitud en Missouri. Esto habría obli-

${ }^{17}$ Lewis, American, 1998, p. 112.

${ }^{18}$ Citado en ibid., p. 146.

${ }^{19}$ Bemis, Jobn, 1965, pp. 24-25, 64-65.

${ }^{20}$ Una excelente descripción de cómo la crisis de Missouri empezó a exacerbar las tensiones en las secciones se encuentra en Freehling, Road, 1990, pp. 144-161. gado a una confrontación decisiva con los estados esclavistas y habría originado una nueva unión de estados norteños libres. "Si la Unión debe disolverse", concluía Adams, "la esclavitud es precisamente el asunto sobre el cual debería quebrarse. Sin embargo, por el momento esta contienda ha sido puesta a descansar." ${ }^{21} \mathrm{La}$ crisis de Missouri había convencido a Adams de que sólo una confrontación catastrófica podría eliminar la esclavitud; también lo había dejado temeroso de que la expansión de la esclavitud acelerase el terrible día del ajuste de cuentas.

Antes de la crisis de Missouri, Adams había aceptado la esclavitud como una necesidad económica y no vislumbraba ningún obstáculo interno en contra de la expansión de la nación hacia el Pacífico. No obstante, después de la controversia sobre admitir a Missouri como un estado esclavo, Adams creía que adquirir Texas pondría en peligro a la Unión. En abril de 1820 Adams escribió que la nación estaba amenazada por la combinación del "crecimiento desmedido de su territorio y el asunto de la esclavitud". Al revivir el problema de la esclavitud, la adquisición de Texas podría "dividirnos en dos". ${ }^{22}$ Como la idea de Adams de extender la nación hacia el Pacífico se había expresado en términos del destino providencial, del mismo modo el surgimiento de sus dudas era un eco de la advertencia clásica de que al expandirse la república las diferencias internas provocarían que la disolución cívica se volviera cada vez más probable. Otros empezaron a expresar el mismo miedo a la fragmentación nacional en términos similares.

21 Adams, Selected, 1946, p. 307.

${ }^{22}$ Adams, Menoirs, 1969, t. 5, p. 68. 
En el verano de 1819 el galsinete de Monroe había considerado de manera beligerante ocupar Texas si España seguía deteniendo su ratificación. Sin embargo, después de la crisis de Missouri, Monroe advirtió que adquirir más "territorio, hacia el oeste y el sur, implica[ba] dificultades, de naturaleza interna, lo que amenaza[ba] a la propia Unión". ${ }^{23}$ En 1836 , Adams explicaría que el presidente Monroe había favorecido el río Sabine como la frontera sudoccidental en 1819 porque "ampliar las fronteras provocaría que nuestra Unión resultara tan cargada que se rompería en pedazos por su propio peso". ${ }^{24}$ Tras desechar la idea del destino providencial, Monroe, según como lo recordaba Adams, había adoptado el lenguaje del republicanismo clásico: las repúblicas no podían expandirse sin autodestruirse.

Para algunos, la perspectiva de añadir a Texas a la Unión había revivido viejos miedos seculares de que las repúblicas no podían expandirse más allá de límites finitos. Para otros, particularmente de los estados sudoccidentales como Tennessee y Kentucky, abandonar Texas traicionaba el futuro providencial del país. En 1820, Henry Clay introdujo una legislación que anularía el Tratado Transcontinental. Haciéndose eco de los editoriales en el Oeste que denunciaban el tratado por renunciar a Texas, explicaba que era "conforme a la providencia y un resultado inevitable del principio de población que la

${ }^{23}$ Monroe, Writings, 1902, t. 6, pp. 119-123. Monroe expresó la misma opinión a Jackson el 23 de mayo de 1820 , y a Gallatin el 26 de mayo de 1820 , véase ibid., t. 6, pp. 126-152. Todo el episodio se discute en Ammon, James, 1971, pp. 409-426.

${ }^{24}$ Adams, "Speech", 1836, p. 6. totalidad del continente, incluyendo Texas, habría de ser poblado con el transcurso del tiempo". ${ }^{25}$ "El magnífico valle del Mississippi es nuestro", declaró el senador Benton en uno de los varios editoriales que escribió denunciando la cesión de Texas, "y desdichado de aquel estadista que ose rendir una sola gota de su agua, un centímetro de su suelo, a cualquier potencia extranjera". ${ }^{26}$

Después de 1820, los dirigentes nacionales ya no estuvieron de acuerdo en que adquirir Texas, junto con toda la mitad occidental del continente, fuese necesario para lograr un desarrollo nacional integrado. Mientras algunos seguían usando el lenguaje del destino providencial al reclamar la adquisición de ese estado, otros habían empezado a imitar el vocabulario cívico del republicanismo clásico cuando expresaban sus temores de una desintegración social. La división que surgía alrededor de la esclavitud había otorgado nueva relevancia a la advertencia republicana clásica de que los intereses divergentes dentro de una república en expansión originaban que la disolución se tornara inevitable.

\section{LA DEFENSA DE LA INTEGRIDAD CÍVICA DE MÉXICO}

Crucificado por Andrew Jackson en las elecciones de 1828, Adams resucitó en las elecciones del Congreso de 1830 y ganó un asiento en la Cámara de Representantes de Estados Unidos, con lo que regresó a la refriega de la política nacional para oponerse al "íncubo del jacksonia-

${ }^{25}$ Clay, Works, 1904, t. 6, p. 216.

${ }^{26}$ Benton, Thirty, 1854, t. 1, p. 15. 
nismo" que había caído sobre el país en las elecciones de $1828 .{ }^{27}$ Adams explicaba. "Pues yo, que estudié en la escuela de Cicerón, debo decir: Defindi republicam adolescens; non deeram sensex" [No traicionaré en la vejez a la república qué he defendido en mi juventud]. Sin embargo, como congresista, Adams empezó a defender un ideal republicano más antiguo que, de hecho, había sido eclipsado por la visión nacional que él mismo había defendido hasta que empezó a encabezar la oposición a la expansión jacksoniana. Después de que los jacksonianos comenzaron a intentar anexarse Texas, Adams estaba dispuesto a separarse de una unión que incluyera a Texas y a los territorios mexicanos adyacentes. La república, empezó insistiendo, no podría expandirse a través de los territorios del norte de México sin transformarse en un imperio despótico.

El problema de admitir que Texas formara parte de la Unión surgió en un clima político de profundización de la discordia nacional sobre la esclavitud. El estancamiento de la decisión de admitir a Missouri como un estado esclavo desde 1820 había sido un punto culminante para el surgimiento de la polarización entre el Norte y el Sur; otro momento decisivo había sido la confrontación sobre el esfuerzo de Carolina del Sur por nulificar los aranceles en 1832. La tensión se había intensificado a raíz de la revuelta de esclavos de Turner y la abolición británica de la esclavitud en las Indias Occidentales; la Sociedad Americana Antiesclavista se formó en 1833; los esfuerzos por distribuir

${ }^{27}$ La presidencia de Adams y la cristalización de la oposición de Jackson se discuten en Bemis, John, 1965, caps. 5-9. Otro debate útil se encuentra en Hecht, John, 1972, caps. 18-21. textos en contra de la esclavitud en el Sur fueron bloqueados mediante la violencia y la intimidación; la campaña en demanda de la abolición de la esclavitud en el Distrito de Columbia impulsó la ley mordaza de Pinckney que evitaba que los miembros del Congreso recibieran peticiones antiesclavistas y debatieran cualquier asunto relacionado con la esclavitud. La actitud defensiva y claustrofóbica que sentían muchos sureños se tornó cada vez más frágil cuando Andrew Jackson incitó al moderado neoyorquino, Martin van Buren, a encabezar la candidatura demócrata en la elección presidencial de $1836 .^{28}$

En la primavera de 1836 , mientras se profundizaban las divisiones en torno a un conjunto de asuntos relativos a la esclavitud, el surgimiento de una nueva controversia -anexar Texas a la Unión o no hacerlo- añadió leña a un fuego ya muy encendido. En marzo de 1836 Texas había declarado la independencia de México; en abril, Sam Houston había derrotado al ejército de Santa Ana en San Jacinto; en mayo de 1836, cuando en la Cámara de Representantes se debatía la ley mordaza y el Senado estaba considerando medidas federales para interceptar la literatura "incendiaria" e impedir que se enviara por el correo estadunidense, ambas cámaras empezaron a considerar las solicitudes de reconocimiento y anexión de Texas. ${ }^{29}$

La $24^{\mathrm{a}}$ Legislatura había empezado a debatir el asunto en abril, impulsado por un diluvio de comunicados y peticiones

${ }^{28}$ Las complejas tensiones sociales del momento se describen en Freehling, Road, 1990, "Part vl, The Annexation of Texas". Véase también Miller, Arguing, 1996.

${ }^{29}$ Smirh, Annexation, 1911, p. 53. 
de Tennessee, Kentucky, Carolina del Sur y del Norte, Mississippi, Ohio, Filadelfia, e incluso Connecticut, que pedían el reconocimiento y la anexión de Texas. ${ }^{30} \mathrm{Sin}$ embargo, cuando se introdujo una resolución para solicitar este reconocimiento, Adams se las arregló para envenenar la propuesta, condenando la rebelión de Texas como una guerra de conquista librada para "restaurar la esclavitud donde había sido abolida". ${ }^{31}$ Para redefinir la rebelión como un esfuerzo por expandir la esclavitud del Sur a expensas de la soberanía mexicana, Adams empleaba el testimonio de su nuevo conocido y colega; Benjamin Lundy.

Benjamin Lundy, quien nació en 1789 , pertenecía a una cuarta generación de cuáqueros y se había vuelto devoto de la causa abolicionista después de trabajar como aprendiz de talabartero en Wheeling, Virginia. ${ }^{32}$ En 1815 , después de abrir una talabartería en St. Clairsville, Ohio, Lundy organizó su primera asociación antiesclavista, la Union Humane Society, que se convirtió en modelo para las casi 1000 sociedades antiesclavistas que empezaron a tener actividad para evitar que Texas se anexara a la Union en $1836 .{ }^{33}$ A mediados de la década de 1820, Lundy había intentado establecer asentamientos de negros en Canadá y en Haití, donde esclavos emancipados, en posesión de sus derechos políticos, podrían demostrar su capacidad

${ }^{30}$ Rather, Recognition, 1911, p. 213.

31 Debates in Congress, $24^{\circ}$ Congreso, 1a. sesión, pp. 3519-3522.

${ }^{32}$ Lundy, Life, 1847, pp. 14-15.

${ }^{33}$ Lundy sostenía que su plan "era casi el mismo que aquel que funcionó de manera eficiente 20 años después y que luego adoptaron casi mil sociedades antiesclavistas". Ibid., p. 17. innata para una existencia cívica íntegra. Hacia 1828, Lundy empezó a considerar a Texas como la ubicación ideal para un asentamiento de negros.

Después de una visita inicial a Texas en 1828, Lundy escribió que con el gobierno mexicano Texas era una región "donde el hombre sin distinción de color o condición es visto como el ser que la Deidad había creado, libre e independiente". ${ }^{34}$ Una floreciente colonia texana de esclavos emancipados, escribió Lundy en otro número, demostraría a los estadunidenses que el negro "puede adaptarse para la libertad y el autogobierno con perfecta facilidad y seguridad" 35

Después de tres viajes y tres años de esfuerzo, finalmente en la primavera de 1835 Benjamin Lundy recibió de manos del gobernador de Tamaulipas un financiamiento empresarial para una colonia. Se le concedieron 138000 acres, cuya ubicación exacta sería definida por él, con el permiso de instalar 250 familias en un plazo de dos años. ${ }^{36}$ Cuando el estallido de hostilidades en Texas tornó irrealizables sus planes de colonización, Benjamin Lundy regresó a Estados Unidos convencido de que la rebelión texana representaba una amenaza terrible para el futuro de la república.

Lundy la condenó en una andanada de nueve ensayos, publicados por primera vez en la National Gazette y luego reimpresos en un panfleto titulado The Origin and True Causes of the Texas Revolution Commenced in the Year 1835 (El origen y. las

${ }^{34}$ Genius of Universal Emancipation, 12 de diciembre de 1831:

${ }^{35}$ Genius of Universal Emancipation, 22 de noviembre de 1832.

${ }^{36}$ Dillon, "Benjamin", 1959, p. 48. 
causas verdaderas de la revolución de Texas iniciada en el año de 1835). En una versión ampliada esto se convirtió en The War in Texas: A Review of Facts and Circumstances, Showing That this Contest is the Result of a Long Premeditated Crusade against the Government, Set on Foot by Slavebolders, Land Speculators, etc., with the View of Re-Establishing, Extending, and Perpetuating the System of Slavery and the Slave Trade in the Republic of Mexico (La guerra de Texas: una revisión de los hechos y circunstancias que demuestra que esta contienda es resultado de una cruzada premeditada por mucho tiempo en contra del gobierno, iniciada por propietarios de esclavos, especuladores con terrenos, etc., con el objetivo de restablecer, extender y perpetuar el sistema esclavista y el comercio con esclavos en la república de México). La culminación de la fascinación de Lundy por la armonía entre latinos, negros, indios y anglosajones que había presenciado en el norte de México, The War in Texas (La guerra de Texas), se convirtió en la fuente principal para la oposición whig abolicionista a la anexión durante los siguientes nueve años.

Los polémicos textos de Benjamin Lundy fueron adornados con imágenes cristianas e imbuidos de un espíritu absolutista de certeza moral. Sin embargo su argumento en contra de la anexión de Texas se basaba en la doctrina republicana clásica, más que en un principio estrictamente religioso o moral. War in Texas afirmaba que la apropiación de Texas destruiría el fundamento secular de la república. Como entidad orgánica, la república implosionaría si una ciudadanía activa no mantenía el equilibrio institucional que por sí mismo garantizaba la estabilidad política. Lundy explicaba:
Ya no podemos disfrazar el hecho de que los defensores de la esclavitud están resueltos, a cualquier costo, a obtener el territorio de que se trata, de ser posible con el propósito reconocido de añadir cinco o seis estados esclavistas más a esta unión: debe considerarse adecuadamente y permitir que la voz pública, desde todo rincón de la república, denuncie en tono fulminante el procedimiento profano. Debe tomarse en cuenta que el sistema esclavista ha sido abolido en Texas pot el gobierno mexicano. Ahora es un estado libre. Difícilmente podría caer sobre nuestro país UNA MALDICIÓN MAYOR que la anexión de un inmenso territorio a esta república si el sistema esclavista de igual modo hubiera de restablecerse ahí.

La "maldición" que invoca Lundy no es bỉblica, sino cívica: la adquisición de Texas pondría a la nación bajo el "yugo" de una facción, la esclavocracia, que subordinaría otros intereses dentro de la república.

Se abriga la esperanza [explicaba Lundy con fervor] de que los esfuerzos de los mexicanos se paralicen así y de que la posesión del territorio retenido por los revolucionarios hasta la siguiente reunión del Congreso de Isstados Unidos, cuando la independencia de la República Texana [Texian en el original] pueda reconocerse formalmente $y$ en adelante admitirse, como un estado independiente, en esta confederación. Ya se ha decidido del todo sobre ésta, "La Combinación". Es el ultimátum de su gran diseño. Sus miembros tienen mayoría en los consejos de la nación, y como coinciden los sentimientos de la cabeza ejecutiva con los suyos, el gobierno se encuentra totalmente bajo su influencia controladora, y con seguridad lograrán su objetivo, a menos que el pueblo de nuestros estados libres se levante de su 
apatía y exprese sus sentimientos de manera directa y decidida, para inducir a nuestros senadores y representantes en el Congreso a que se opongan a esta medida. PERMITTASE QUE LA VOZ PÚBLICA SE ALCE FULMINANTE... Que la nación sea despertada por completo y aún podrá solucionarse todo. De otra manera, el Demonio de la Opresión triunfará y nuestros hijos tendrán que lleyar sus cadenas, o la sangre correrá en torrentes, y la tierra será bañada con su sangre carmesí.

El lenguaje, cargado de imágenes cristianas, se emplea explícitamente para lanzar una demanda cívica: la apropiación de los territorios del norte de México convertiría a los ciudadanos estadunidenses en bárbaros y a la república en un imperio despótico.

¿Sancionarán ustedes esta abominable ofensa [preguntaba Lundy en las conclusiones de The War in Texass, se involucratán en la profunda criminalidad, y tal vez en los horrores de la guerra, para establecer la esclavitud en una tierra de libertad? ¿ $Y$ de esa manera expondrán su cuello y los cuellos de sus descendientes bajo los pies de los tiranos dominantes del Sur por los siglos venideros? ?7 $^{37}$

El sentido de rectitud urgente y su reclamo cívico de que la anexión de Texas minaría la base secular de la república fueton adoptados por opositores de todas partes. El 18 de marzo de 1836, un documento de vanguardia whig, The National Intelligencer, respaldó a Lundy al sostener que el "complot" para adquirir Texas sería "una maldición profunda y persistente para el país". En el Congreso, John Quincy

${ }^{37}$ Lundy, War, 1836, pp. $2-4$.
Adams apoyó el llamado de Lundy a oponerse a los incipientes esfuerzos por anexarse Texas. Lo hizo en un discurso famoso, "Sobre la resolución conjunta para distribuir raciones para los fugitivos perjudicados que huyen de las hostilidades indias", presentado antes en la Cámara de Representantes el 25 de mayo de 1836. Adams empleó el discurso tanto para refutar el primer artículo de la ley mordaza de Pinckney, como para sostener que el Congreso no tenía autoridad sobre la esclavitud en los estados y para proponer el reclamo de Lundy de que la expansión de la esclavitud ponía en peligro los fundamentos cívicos de la república. Debido a que se difundió tan ampliamente lo mismo en México como en la prensa abolicionista de Estados Unidos, Adams describió el discurso en su diario como, "con mucho, el discurso más notable que haya escrito". ${ }^{38}$

Pasando de otros temas a Texas, Adams imitaba a Lundy al transformar a México en un símbolo de libertad, al tiempo que convertía a Texas en un emblema del despotismo.

La guerra que ahora estalla en Texas lembestía Adamsl es una guerra para el restablecimiento de la esclavitud donde fue abolida [...] y se ha hecho todo esfuerzo posible por llevarnos a la guerra del lado de la esclavitud. ¿Cuál será su reivindicación en la inminente guerra con México? Agresión, conquista y el restablecimiento de la esclavitud donde se ha abolido. En esa guerra, señor, los estandartes de la libertad serán los estandartes de México, y los de ustedes, me sonrojo al pronunciar la palabra, serán los estandartes de la esclavitud. ${ }^{39}$

\footnotetext{
${ }^{38}$ Adams, Memoirs, 1969, t. 9, pp. 31.

${ }^{39}$ Adams, "Speech", 1836, p. 6.
} 


\section{SECUENCIG}

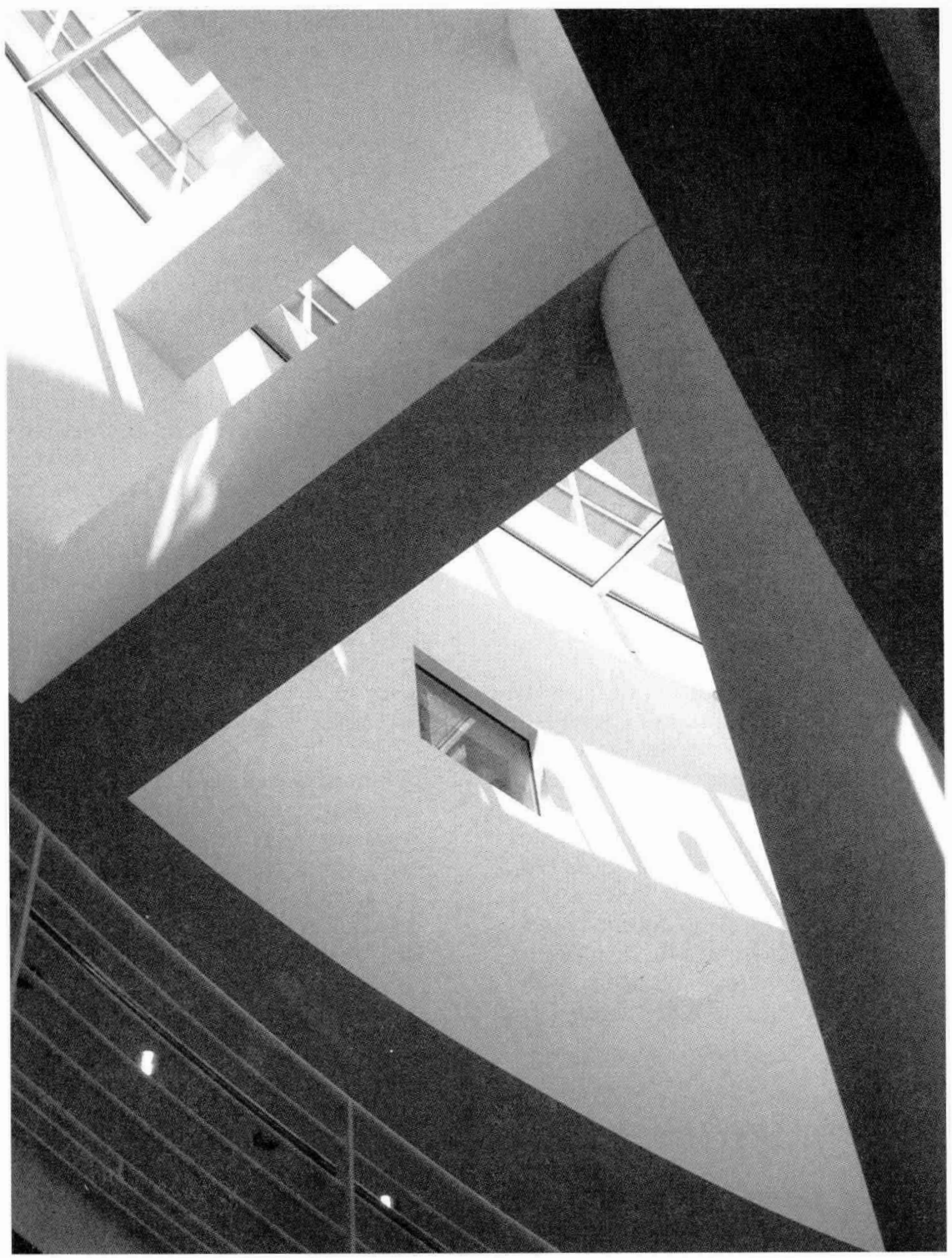


Al presentar su provocativa afirmación, Adams confiaba - directamente- en la evidencia exaltada que Benjamin Lundy había acumulado durante sus tres excursiones a Texas y a Tamaulipas. Adams había conocido a Lundy en 1835 y había leído muchos de sus artículos antes de que el reconocimiento se convirtiera en un tema de debate en el Congreso. Poco después de que Adams empezó a plantear sus argumentos en la Cámara, agradeció a Lundy por proporcionarle "casi todos los datos" que había empleado en los debates del Congreso. ${ }^{40}$ Un mes después, Adams confío a Lundy:

No veo alternativa, sino que toda la confederación mexicana está destinada a ser aplastada por nuestros especuladores de tierras y esclavistas y que la disolución de nuestra propia Unión deberá preceder la última lucha entre la esclavitud y la libertad. ${ }^{41}$

Destacando la abolición de la esclavitud en México, Adams subrayaba la fechoría de anexar Texas. Sin embargo, al defender la integridad cívica de México, Adams también denunciaba la expansión jacksoniana como una amenaza de extender demasiado las fronteras de la república. Cuando explicó que Monroe se había inclinado por el río Sabine como la frontera sudoccidental a fin de no expandir demasiado las fronteras de la república, Adams preguntó a sus compañeros del Congreso:

En cuanto a la anexión de Texas a nuestra confederación, ¿para qué lo quieren? ¿Acaso

${ }^{40}$ Adams a Lundy, 20 de mayo de 1836, en Lundy, "Life", 1847, p. 61.

${ }^{41}$ Adams a Lundy, 27 de junio de 1836, en ibid. no es su territorio ya lo bastante extenso y difícil de manejar? [...] ¿No son sus fronteras sureña y sudoccidental suficientemente grandes? ¿Por qué están añadiendo regimiento tras regimiento de dragones a su ejército permanente? ${ }^{42}$

Sus colegas, que habían visto al secretario de Estado Adams colocar a la nación en la vía diplomática de la expansión continental, después deben haberlo escuchado con incredulidad.

Es significativo el hecho de que, a pesar de haberse convertido en un defensor de la soberanía territorial de México, Adams no adquirió una nueva fe en que México surgiría como una hermana república igual a Estados Unidos. Como congresista, nunca adoptó el tipo de fe proselitista en el potencial republicano de México que había animado a Henry Clay en la década de 1820. De hecho, Adams esperaba mantener a Estados Unidos lejos de la contaminación de la sublevación crónica de la vida cívica de México.

La historia de todas las colonias españolas americanas emancipadas ha sido una serie de guerras convulsivas [explicaba Adams en su discurso de 1836] [...] esto me hace temblar ante el pensamiento de conectar indisolublemente nuestros destinos con el de ellos. ${ }^{43}$

Al abogar por la soberanía de México, Adams nunca se despojó de su desdén por Latinoamérica.

No obstante, a pesar de su perdurable hispanofobia, Adams se convirtió en una figura importante en México, donde se

42 Adams, "Speech", 1836, p. 3.

${ }^{43}$ Ibid., p. 4. 
publicaban muchos de sus discursos que denunciaban la anexión. ${ }^{44}$

Una publicación mexicana introducía el discurso de Adams de 1836 con una nota que señalaba que los pronunciamientos de éste eran

las efusiones de un alma sublimada, que se eleva sobre la corrupción de la época, se atreve a promulgar la verdad en su pureza y aboga en defensa de los principios de justicia tan escandalosamente pisoteados en su país con respecto al asunto de Texas. ${ }^{45}$

Aunque permaneció con dudas sobre la capacidad de los mexicanos, Adams defendió con voz estridente la soberanía de México en el Congreso y ante el público de Estados Unidos. Por ello se ganó la gratitud de la ciudadanía mexicana. ${ }^{46}$

Cuando Adams se convirtió en una figura heroica para los mexicanos, también los emblemas de la civilidad de México se usaban a menudo para adornar con imágenes las alocuciones de aquél en la prensa abolicionista. Un panfleto presentaba con orgullo el discurso de Adams de 1836 que denunciaba la anexión. En la página concluyente del discurso hay una gran moneda mexicana con una leyenda que explica: "Las armas de la moneda de la república mexicana son el águila de la libertad destruyendo a la serpiente, la tiranía, y en el reverso lleva el gorro de la libertad irradiando su luz universalmente." ${ }^{47}$ Cuando

${ }_{44}$ Brack, Mexico, 1975, p. 123.

45 Este prefacio lo cita, sin referencias específicas, Lundy, War, 1836, p. 33.

${ }^{46}$ La situación de Adams en la prensa mexicana durante la década de 1830 se detalla en Brack, Mexico, 1975, p. 123.

${ }^{47}$ Estos emblemas están en The Legion, 1843.
Adams se convirtió en un símbolo de la rectitud cívica dentro de México, "México" se usó en la prensa abolicionista como una imagen simbólica de la libertad amenazada por la potencia esclavista invasora.

En 1836 Adams había contribuido a redefinir la revolución texana como un esfuerzo por expandir la esclavitud más que como extensión de la revolución americana. Al hacerlo convirtió el asunto del reconocimiento de Texas en una controversia nacional contenciosa. No fue sino hasta que el sucesor de Jackson, Martin van Buren, había sido electo presidente sin contratiempos, cuando la administración de aquél le pidió al Congreso otorgar reconocimiento diplomático a la "república" de Texas. Durante los siguientes nueve años, Adams combatió al bando anexionista con sorprendente vehemencia. Para cuando John Calhoun propuso su tratado de anexión al Senado en 1844, todo congresista de los trece estados sureños tenía suficientes razones para coincidir con I. I). Ingram en que John Quincy Adams era tan peligroso para el Sur como "un loco incendiario en un almacén de pólvora". ${ }^{8}$

Cuando el $25^{\circ}$ Congreso inició deliberaciones en diciembre de 1837, Adams presentó un paquete de peticiones en contra de la anexión. También llevó solicitudes de la Sociedad de Paz de Nueva York, organizada recientemente, para establecer una corte internacional de naciones donde pudieran arbitrarse las principales diferencias entre México y Estados Unidos. ${ }^{\text {(t) }}$

${ }^{48}$ Graebner, Empire, 1955, p. 19.

15) Las largas negociaciones finalmente culminaron en el tratado del 11 de abril de 1839; se sometieron las principales demandas de Estados Unidos en contra de México ante una comisión mixta con una disposición para el rey de Prusia para designar un 
Cuando la mayoría de la administración votó por postergar las resoluciones contra Texas, la Cámara fue inundada por infinidad de nuevas peticiones, con "decenas de miles" de firmas en contra de la "anexión de territorios extranjeros de extensión inmensa y desconocida con el propósito de impulsar la propagación de la esclavitud". ${ }^{50}$ Las legislaturas estatales de Rhode Island, Vermont, Michigan, Ohio y Massachusetts entregaron a la Cámara más resoluciones que denunciaban la anexión. Como respuesta, Tennessee, Alabama y otros estados sureños presentaron ante la Cámara comunicados que respaldaban la anexión de Texas. ${ }^{51}$

Hacia junio de 1838, el Comité sobre Asuntos Exteriores de la Cámara recomendó que todas las peticiones y resoluciones en favor y en contra de la anexión se postergaran. Sin embargo, la recomendación no detuvo a Adams. Durante las tres semanas restantes en que el Congreso continuó sesionando, Adams tomó la palabra durante la hora matutina reservada a temas del Comité de Asuntos Exteriores. Su discurso maratónico condenaba la postergación de las peticiones y la conspiración para apropiarse de las provincias del norte de México. El panfleto, compilado a partir de sus diarias participaciones con fines dilatorios, abarcaba 130 páginas en letra pequeña. ${ }^{52}$

árbitro. Aunque la comisión no podía resolver las diferencias entre los dos países, sí sirvió como un programa de acción para las Conferencias de La Haya y la Corte de Arbitraje Internacional de La Haya que se establecieron después, Bemis, Jobn, 1965, p. 364.

${ }^{50}$ Ibid., p. 365.

${ }^{51}$ Ibid.

${ }^{52}$ El panfleto tenía por título Speech of Jobn Quincy Adanis of Massacbusetts, upon the Right of the People,
Para el final del $25^{\circ}$ Congreso, Adams y sus aliados abolicionistas habían elevado tanto el costo político de apoyar la anexión, que Van Buren continuaba sin estar dispuesto a apoyar la causa. En octubre de 1838 la delegación de Texas en Washington retiró formalmente su propuesta de anexión. ${ }^{53}$

Poco después de que John Tyler se convirtiera en presidente, en abril de 1841 , empezó a buscar la dudosa gloria de anexar la República de la Estrella Solitaria. Aunque era un ferviente partidario de los intereses sureños, Tyler aún consideraba la expansión territorial como un imperativo económico para todo el país. La depresión económica progresiva que había comenzado con la crisis bancaria de 1837 había convencido a Tyler de que abrir territorios nuevos y adquirir nuevos mercados era necesario para sostener el crecimiento económico nacional en el futuro predecible. $\mathrm{Al}$ adquirir Texas, los agricultores texanos monopolizarían la producción de algodón, mientras que los norteños adquirirían un vasto mercado interno para bienes manufacturados. Mediante la adquisición de los puertos californianos, todas las regiones del país podrían vender en los vastos mercados no aprovechados de Asia. ${ }^{54}$ Tyler escribió a su primer secretario de Estado, Daniel Webster: "Nuestro trayecto está tan claro ante nosotros, que no podemos estar equivocados. Debe-

Men and Women, to Petition; on the Freedom of Speech and of Debate in the House of Representatives... on the Resolutions of Seven State Legislatures, and the Petitions of More than One Hundred Tbousand Petitioners, Relating o the Annexation of Texas to this Union, impreso por Gales y Seaton, Washington, 1838.

${ }^{53}$ Smith, Annexation, 1911, p. 65.

${ }^{51}$ Hietala, Manifest, 1985 , p. 61. 
mos mirar hacia todo el país y hacia todo el pueblo." 55

Los esfuerzos de Tyler por ganarse el apoyo público para su programa expansionista empezaron en serio cuando el congresista del partido Whig de Virginia, Thomas Gilmer, escribió un apasionado editorial, respaldando la anexión, para el Baltimore Republican and Argus el 10 de enero de $1843 .{ }^{56} \mathrm{Al}$ artículo de Gilmore siguió una serie de editoriales de apoyo en los principales diarios democráticos, como The St. Louis Enquirer, The New York Herald, The Daily Madisonian y The Democratic Review. ${ }^{57}$

Con los constantes elogios del destino de los angloamericanos y las denuncias de la incapacidad de los mexicanos, los propagandistas de Tyler apelaban a los principios fundamentales de lo que llegó a conocerse como "destino manifiesto". Por ejemplo, la carta de Gilmer condenaba a los opositores a la anexión como carentes de fe en el destino común de la nación. "Estos sentimientos [patrióticos] ya están extintos", explicaba Gilmer, "en ese regazo que no se enciende al contemplar la prosperidad y grandeza sin paralelo de nuestro país, cuando los albores del futuro los presagian".

Al declarar que "las naciones como los individuos deben vivir a la altura de su destino", Gilmer hacía un llamado a la nación para que se expandiera hacia los territorios del norte de México. Por carecer éste de la capacidad cívica, ya fuera para sostener o bien para desarrollar sus tierras fronterizas, estaba garantizada la

${ }^{55}$ Smith, Annexation, 1911, p. 104.

${ }^{56}$ El ensayo de Gilmore está disponible convenientemente en Merck, Slavery, 1972, p. 200.

${ }^{57}$ Hietala, Manifest, 1985, pp. 10-40. anexión de los territorios mexicanos a Estados Unidos. Gilmer explicaba que México "estaba destinado por un tiempo a continuar en un estado de caos civil, sin mostrar signos de energía sino de convulsiones espasmódicas ocasionales". ${ }^{58} \mathrm{Me}$ diante el establecimiento de una marcada antítesis entre los "destinos" de México y los de Estados Unidos, Gilmer apelaba explícitamente a la ética nacionalista que habría de triunfar durante la administración de Polk.

Animada por la audacia de Adams en el Congreso, y aprovechando el ímpetu de victorias anteriores, la oposición se movilizó en contra de la renovada oferta de Tyler por Texas. Durante el último año de la administración de éste, los periódicos whig y los abolicionistas se inundaron de sermones, artículos, ensayos y discursos con reiteraciones del argumento cívico familiar en contra de la anexión que Lundy y Adams habían empezado a difundir en 1836.

En una serie de artículos publicados originalmente en el New York Evening Post, Theodore Sedgwick hizo un llamado a Estados Unidos para promover la estabilidad política de México y no conquistar sus territorios.

La anexión de Texas [escribió Sedgwick], en lugar de fortalecer la Unión, la debilita, justo en la medida en que añade una gran línea fronteriza por ocupar y defender. Una república amistosa o neutral en nuestra frontera es de una importancia inmensamente mayor para nosotros desde todo punto de vista militar. 59

\footnotetext{
${ }^{58}$ Merk, Slavery, 1972, p. 201.

${ }^{50}$ Sedgwick, Thougbts, 1844, p. 31.
} 
En la literatura de oposición, México surgía repetidamente como un emblema de libertad cívica amenazada por la esclavocracia invasora. Uno de los típicos panfletos abolicionistas, The Legion of Liberty! and Force of Truth! (diciembre de 1843), anunciaba que la Sociedad Antiesclavista Americana había resuelto "que consideramos el proyecto de anexar Texas a estos Estados Unidos [...] como injusto y pérfido para México y para este país, y equivalente, si se lleva a cabo, a la disolución de la Unión". Sobre estas palabras pequeñas, con poco espacio entre ellas, había una imponente imagen del águila mexicana sosteniendo una serpiente retorcida en su pico. La leyenda explicaba, "EL ÁGUILA LIBRE DE MÉXICO APRISIONANDO A LA VÍBORA DE SANGRE FRÍA, LA TIRANÍA DE TEXAS."

Del mismo modo que los propagandistas en favor de la anexión, como Walker y Gilmore, intentaban difamar a México, sus oponentes defendían al país -donde la esclavitud estaba prohibidacomo incuestionablemente civilizado. En un discurso típico, el beligerante abolicionista de Kentucky, Cassus Clay, exclamó: "Protesto en contra de esta invocación de nuestra simpatía en nombre de Texas y contra estas injustas denuncias sobre México." El pueblo mexicano, afirmaba Clay, estaba "inspirado por esa declaración de la independencia americana a la que Texas en su deslealtad había renunciado". En 1821 México había ganado su independencia de España; en 1824, el gobierno constitucional se había establecido; en 1829 "este México tan maltratado" había proscrito la esclavitud. Clay insistía en que anexar la tierra de una república ve-

${ }^{60}$ The Legion, 1843 , p. 8. cina imbuida de los ideales revolucionarios de América daría a México razón para reclamar "la simpatía universal y la ayuda de todas las naciones". La anexión violaría la soberanía de México, corrompería la Constitución federal y disolvería la república de Estados Unidos. ${ }^{61}$

Al oponerse a la campaña de Tyler, John Quincy Adams alcanzó la cima de su propia transformación en un oponente espartano a la expansión jacksoniana. Habiendo obligado a las administraciones de Jackson y Van Buren a abandonar todo esfuerzo por la anexión, Adams insistió en su ataque en contra de la oferta renovada de Tyler por Texas con extraordinaria intensidad. "Mientras me quede un remanente de poder físico para escribir y hablar", escribió Adams, revelando la vehemencia de su impulso, "el mundo se retirará de mí antes de que yo me retire del mundo". ${ }^{62}$ Proseguía su campaña con tal audacia implacable, que los expansionistas no habrían de recobrar la ofensiva sino hasta las elecciones de 1844 .

Durante el $27^{\circ}$ Congreso presentó solicitudes a los estados sureños para "adoptar una forma de gobierno republicana" mediante la liberación de todos los ciudadanos esclavizados. ${ }^{63}$ En otra ocasión pidió al orador reglamentar sobre la conveniencia de atender las peticiones que aparentaban provenir de esclavos..$^{61}$ En otro momento presentó una petición de los ciudadanos de Clarksville, Georgia,

${ }^{61}$ Cassus Clay, "Speech of Cassus Clay versus the Annexation of Texas", Niles Register, 30 de diciembre de 1843, pp. 212-214.

${ }^{62}$ Adams, Memoirs, 1969 , t. 10, p. 49.

${ }^{63}$ Congressional Globe, $27^{\circ}$ Congreso, 22 de enero de 1842, p. 158.

${ }^{64}$ Bemis, Jobn, 1965, p. 343. 
solicitando al Congreso retirarlo de su puesto como presidente del Comité sobre Asuntos Extranjeros debido al hecho de que estaba "poseído por una especie de obsesión por todos los temas relacionados con personas tan morenas como los mexicanos". ${ }^{65}$ En repetidas ocasiones, las provocadoras estratagemas de Adams causaron en el Congreso espasmos de violentos debates que proporcionaban nuevas oportunidades de que "el loco de Massachusetts" denunciara al bloque esclavista y sus maquinaciones. ${ }^{66}$

Poco después de que James Tyler se convirtiera en presidente en 1841, Adams detonó su bomba más explosiva al presentar peticiones de ciudadanos de Haverhill, Massachusetts, para que el Congreso adoptara de inmediato "medidas pacíficas para disolver la Unión de esos estados". Primero hubo una explosión, escribe el biógrafo de Adams, Samuel Bemis, "y entonces todo Babel cayó sobre el representante de Plymouth" ${ }^{67}$ En medio de la conmoción, el congresista de Virginia, Thomas Walker, presentó una resolución para censurar a Adams; el congresista de Kentucky, Thomas F. Marshall, sobrino de Johri Marshall, presentó una resolución más extrema, acusando a Adams de "perjurio y alta traición". Durante las dos semanas de encarnizado debate sobre la moción para censurar a Adams, el Congreso fue inundado por peticiones provenientes del Norte en protesta contra la

${ }^{65}$ Ibid., p. 424.

${ }^{66}$ Varios estudiosos han examinado con detalle la guerra parlamentaria de Adams en contra del bloque sureño. El relato más informativo sobre toda la carrera de Adams en el Congreso sigue siendo el de Bemis, Jobn, 1965. Véase también Richards, Life, 1986, y Hecht, John, 1972, caps. 21-25.

${ }^{67}$ Bemis, John, 1965, p. 428. resolución de Marshall. Para terminar con el espectáculo, el Congreso finalmente votó 106 contra 93 a favor de posponer la moción de censura. ${ }^{68}$

Inmediatamente después de su "juicio" por traición en el Congreso, Adams se convirtió en el oponente más notorio de la expansión jacksoniana en el país. Tras haberlo observado desde la galería, el líder abolicionista Theodore Dwight Weld escribió: "ésta es la primera victoria sobre los esclavistas en conjunto desde la fundación del gobierno, y a partir de ahora su caída se precipitará". ${ }^{69}$ William Lloyd Garrison saludó a Adams colocando un nuevo lema encabezando su página editorial, "REVOCAR LA UNIÓN." Las sociedades antiesclavistas a lo largo del país aprobaron resoluciones que pedían la desunión. Una de ellas denunció a la Constitución como "un pacto con la muerte y un convenio con el infierno". ${ }^{70}$ Henry Clay escribió a Adams que "con cada gran emergencia aparecía un hombre adecuado para el servicio de conducirnos con seguridad a través del peligro inminente. En la ocasión actual ese noble oficio es suyo." $71 \mathrm{Al}$ continuar desafiando a la mayoría de la administración en el Congreso, Adams no sólo estaba galvanizando la opinión pública del Norte en contra de la esclavitud, también estaba manteniendo el costo político de apropiarse los territorios mexicanos en un nivel prohibitivamente alto.

Celebrada en el Norte, "la siseante serpiente de Braintree" fue satanizada a lo largo del Sur.

${ }^{68}$ Bemis detalla todo el episodio en ibid., cap. 20, "Trials", pp. 416-448.

${ }^{69}$ Richards, Life, 1986, p. 144.

${ }^{70}$ Kraditor, Means, 1967, pp. 196-217.

${ }^{71}$ Bemis, Jobn, 1965, p. 442. 
Incluso antes de que el presidente Tyler hubiese renovado esfuerzos por anexar Texas, el congresista de Massachusetts estaba recibiendo hasta 200 cartas al mes con amenazas de asesinato procedentes de los estados sureños. ${ }^{72} \mathrm{~A}$ pesar de la cascada de advertencias, ni siquiera el más celoso sureño tenía la temeridad de matar al ex presidente cuyo padre había contribuido a escribir el borrador de la Declaración de Independencia. Asimismo, John Quincy Adams estaba demasiado enfadado para morir antes de haber enseñado a cada partidario de los estados sureños cómo el hijo de un patriota defendía a la república de sus nuevos enemigos.

Ciertamente, el rasgo más notable de la campaña de Adams en contra de la expansión jacksoniana era la vehemencia de sus ímpetus. Durante la conmoción sobre sus peticiones de disolver la Unión, Adams escribió en su diario que mientras la "malignidad" de los ataques en contra suya se convirtieron por "su estupidez, no en inocencia, sino en inocuidad", permanecía "inseguro de mi propio control sobre mi propio espíritu". Cuatro quintas partes de los representantes de los estados esclavistas "me crucificarían si sus votos pudieran erigir la cruz". Sus aliados del Norte "me quebrarían en la rueda, si sus votos o deseos pudieran hacerla girar". Cuatro quintas partes de los miembros restantes "me abandonarían al primer indicio de indiscreción de mi parte". Sin embargo, Adams concluyó: "El único peligro descomunal con el que me enfrento es el de mi propio temperamento."73

Aunque la ira de Adams lo ayudaba a movilizar al Norte en contra de la ane-

${ }^{72}$ Richards, Life, 1986, p. 131.

${ }^{73}$ Adams, Memoirs, 1969 , t. 11 , p. 87. xión, también servía para un propósito más oculto. En tanto Adams lanzara su propia furia divina en contra del poder esclavista profano, permanecía ciego a las profundidades de su propia complicidad en las políticas expansionistas que ahora aborrecía. John Quincy Adams podía pasar por alto, pero no negar, que había defendido la invasión de Andrew Jackson de Florida en 1818. Había promovido la expansión de los mercados tanto como Calhoun, la cual había provocado la demanda de algodón y afianzado la esclavitud de vasallos a lo largo del Sur. Había proporcionado el campo de trabajo para la expansión territorial que los jacksonianos ahora estaban intentando consumar. El propio Adams había contribuido a soltar las bestias que ahora trataba de contener.

Por lo ocupado que estaba intentando lavar la sangre de las manos de sus enemigos, Adams no pudo ver nunca la sangre que manchaba las suyas. En ninguna parte de su diario entre 1836 y 1848 , año en que murió, reconoció Adams su propia culpabilidad considerable al promover la expansión jacksoniana. Sin embargo, durante estos mismos años de lucha sin cuartel, en su diario expresó repetidamente la ansiedad de que su poderosa labor no bastó para complacer a Dios Todopoderoso. "Me siento como un constante pecador ante Dios", escribió en una frase típica el 19 de marzo de 1843 "y a menudo necesito que se me amoneste por ello y se me exhorte a buscar la virtud". ${ }^{7.1}$

Afirmar que Adams estaba inusualmente atormentado sería una exageración.

${ }^{74}$ Ibid., p. 341. Adams continuó expresindo dudas similares a lo largo de la última fase de su vida. Justo al final, aún manifestaba su aguda sensación de indignidad espiritual. Véase, por ejemplo, t. 12, pp. 271, 277. 
Llevó una vida larga, vigorosa, plena de buenas acciones y actividades significativas. Disfrutaba de la adulación de sus partidarios y buscaba coordinar sus acciones con sus convicciones. Sin embargo, aunque impidió que tres presidentes tomaran Texas, nunca pudo hacer las paces consigo mismo. La lucha de Adams en contra de la expansión jacksoniana no tuvo igual. No obstante, en las últimas anotaciones en su diario, Adams aún dudaba de ser merecedor de la gracia consoladora de Dios.

El 27 de abril de 1844, The New York Evening Post publicó el tratado de anexión, con su documentación de apoyo, que el secretario de Estado había terminado en secreto con los funcionarios texanos y había presentado al Senado el 12 de abril de $1844 .^{75}$ Los materiales probatorios, filtrados al Evening Post por Benjamin Tappan, un senador antiesclavista de Ohio, llevaron al clímax el debate sobre la anexión. Cuando el Senado finalmente rechazó el tratado en junio de 1844 , los moderados de los partidos tanto Demócrata como Whig habían adoptado la afirmación de Adams de que tomar las tierras mexicanas para expandir la esclavitud habría -en efecto- destruido la república.

A diferencia de los ideólogos, quienes justificarían el programa expansionista del presidente Polk, Calhoun nunca definió la anexión de Texas como el cumplimiento del destino providencial. La anexión, declaró Calhoun, era necesaria para proteger la "institución particular" sureña de la intriga británica y de los abolicionistas radicales. Calhoun expresó su defensa más enfática de la anexión en dos cartas dirigidas al ministro británico Pakenhan,

${ }^{75}$ Merk, Slawery, 1972, p. 57. que se incluyeron entre los documentos publicados en el New York Post. En esas cartas Calhoun argumentaba que anexar Texas evitaría que Gran Bretaña emancipara a los esclavos de Texas y fomentara una rebelión servil en los estados esclavistas. Fracasar en la protección de la esclavitud del Sur, insistía Calhoun, "implicaría la mayor calamidad para todo el país, y en especial para la raza a la que manifresta esforzarse por beneficiar". ${ }^{76}$ Nadie que leyera los argumentos de Calhoun en favor de la anexión en el Evening Post podría dudar que pretendía apropiarse de Texas, y los territorios mexicanos adyacentes, para proteger y expandir la "institución particular" del Sur.

El 9 de junio de 1844, en vísperas de la suspensión, el Congreso rechazó abrumadoramente el tratado de Calhoun por una votación de 16 a 35 . Todos los miembros del partido Whig del Senado, excepto John Henderson de Mississippi, se opusieron. Siete demócratas de Van Buren, junto con Thomas Benton de Missouri, también estuvieron en desacuerclo. Adams y sus aliados, ayudados por John Calhoun, habían descarrilado la propuesta de Tyler por Texas.

El anciano congresista de Massachusetts expresó su gratitud escribiendo:

registro este voto como una salvación, espero, por la intermediación especial de I)ios Todopoderoso, de mi país y de la libertad humana, de una conspiración comparable a la de Lucius Sergius Catilina. ¿Qué no resulte una simple salvación temporal, como aquella preliminar a la conspiración faralmente exitosa de Julio César! La anexión de Texas a esa unión es el primer paso para

${ }^{76}$ Ibid., p. 693. 
conquistar todo México, las islas de las Indias Occidentales, de una monarquía marítima, colonizadora, de tintes esclavistas y de libertad extinta. ${ }^{77}$

Adams tenía todas las razones para sentirse triunfante; había obtenido una victoria extraordinariamente polémica. Sin embargo sus aprehensiones estaban igualmente bien justificadas: los imperativos de la expansión del mercado, entremezclados con una rivalidad de secciones en aumento, estaban creando una presión política abrumadora para expandirse por todo el continente.

Adams, junto con sus colegas whig y abolicionistas, podía alegar razones de alta moral al oponerse a la expansión jacksoniana. Mencionaban convincentemente los desgastados vínculos entre el Norte y el Sur para afirmar que las divisiones internas aumentaban al irse expandiendo la república. Pero mientras que eran capaces de bloquear la anexión lanzando rayos de rectitud contra sus desventurados adversarios, sólo podían proponer una visión estática de la república que se había vuelto obsoleta por el sistema de mercado, creado por la Constitución federal, que estaba impulsando al país hacia el oeste en la década de 1840. Los oponentes de la anexión ofrecieron poco a los inmigrantes que estaban buscando la manera de ingresar en las ciudades del este desde los viejos imperios europeos. Sus argumentos no bastaban para llenar de nuevo las cuentas de los agricultores arruinados durante el Pánico de 1837.

Incluso mientras el tratado de Calhoun estaba siendo derrotado, una nueva coalición de expansionistas del Norte y

77 Adams, Memoirs, 1969, t. 12, p. 49. del Sur se había congelado en la Convención de Nominación Presidencial Demócrata en Baltimore. Ya habían orquestado la nominación de Polk cuando el Senado rechazó el tratado de Calhoun en junio de 1844. Estaban reestructurando los argumentos apremiantes planteados por James Madison en Federalist Papers consistentes en que la república había mejorado con la expansión territorial. ${ }^{78}$ Estaban restaurando la antigua fe nacionalista de Adams de que la nueva nación -la nueva ciudad en lo alto de la colina- estaba protegida en su marcha inexorable a través del continente.

La forma como fue anexada Texas, y lo que sobrevino entonces; son elementos de la historia anterior a la guerra civil. Van Buren fue reemplazado por el expansionista confeso James Polk en la Convención de Nominación Demócrata de 1844. Con un simple $1.4 \%$ de ventaja en el voto popular, Polk ganó la elección prometiendo "reanexar Texas y reocupar Oregón". Considerando la elección de Polk una orden para anexar la República de la Estrella Solitaria, al reanudarse las sesiones el $28^{\circ}$ Congreso empezó a reconsiderarla a principios de enero de 1845 . El estancamiento sobre distintas opciones de resoluciones de anexión finalmente se rompió, después de dos meses de debate, cuando Robert Walker presentó un proyecto de avenencia que el Senado aprobó por sólo dos votos. La guerra con México, que estalló trece meses después, junto con las gigantescas adquisiciones territoriales, se formalizaron en el Tratado de Guadalupe Hidalgo de 1848, y se justificaron apelando a los principios exaltados del Destino Manifiesto que los primeros discursos de Adams habían ayudado a popularizar.

\footnotetext{
${ }^{78}$ Madison, “Ten”, 1961, pp. 82-84.
} 
Cuando Polk presentó su declaración de guerra al Congreso, Adams asumió de nuevo el liderazgo de la oposición a la conquista de los territorios mexicanos. Adams fue uno de los catorce miembros del Congreso que votaron contra la guerra; le dijo a un colega que esperaba que los funcionarios estadunidenses renunciaran a sus comisiones y que los soldados desertaran antes de luchar en una guerra "injusta". 79

La guerra, temía Adams, proporcionaría a los futuros presidentes un precedente para declarar la guerra por decreto ejecutivo.

Se ha establecido ahora como un precedente irreversible lescribió Adams a Albert Galatin] que el presidente de Estados Unidos no tiene más que declarar que la guerra existe, con cualquier nación sobre la Tierra, por el acto del gobierno de esa nación, y la guerra se declara esencialmente.

La guerra le robaría territorio a México; sin embargo, Estados Unidos perdería su integridad cívica. "No es difícil prever lo que su resultado final será para el pueblo de México", escribió, "lo que será para el pueblo de Estados Unidos está fuera de mi previsión y prefiero no mirarlo". 80

Cuando la sesión del Congreso terminó en el verano de 1846, John Quincy Adams regresó a Quincy sintiendo todo el cansancio de sus 79 años. Seguía estando orgulloso de su servicio público y animado por su reelección para un octavo

${ }^{79}$ Richards, Life, 1986, p. 90.

${ }^{80}$ Adams a Albert Gallatin, 26 de diciembre de 1847. Citado en Bemis, John, 1965, p. 500. periodo en el Congreso. ${ }^{81}$ Mirando su vida en retrospectiva, Adams podía escribir que "había disfrutado de una porción del favor de mi país por lo menos igual a mi mérito". Su vida había tenido "graves vicisitudes, pero en general había sido sumamente afortunada". 82

No obstante, aunque permaneció lleno de vitalidad y orgulloso de sus contribuciones, Adams no podía deshacerse del temor persistente de que la suma de sus esfuerzos había dejado insatisfecho al Todopoderoso. En su primera anotación en su diario después de regresar a Quincy, Adams escribió: "la nostalgia que siente mi alma después de una larga vida por contarse entre las bendiciones otorgadas por el Creador a la raza humana es rechazada". Se quejaba: "Después de haber sido obstaculizado, frustrado e inhabilitado en cada etapa de mi camino, ahora mis facultades están declinando día a día y convirtiéndose en simple desvalimiento." 83

A pesar de su creciente sensación de impotencia, Adams continuó teniendo demasiado impulso como para permitir que la edad, la enfermedad o incluso la muerte terminasen con su campaña en contra de los poderes ilimitados que no podían contener ni admitir que había contribuido a desatar. El 20 de noviembre de 1846 , mientras caminaba con un amigo, Adams sufrió de un ataque leve. Tras recuperar sus facultades después de varios días de descanso, Adams explicó en su diario que desde la hora de su colapso

${ }^{81}$ La elección fue el 10 de noviembre de 1846. Adams, de 79 años de edad, fue electo por una mayoría de 1600 votos. Ibid., p. 527.

${ }^{82}$ Adams, Memoirs, 1969, t. 12, p. 206.

${ }^{83}$ Ibid., p. 271. 
"preveo mi deceso y me considero, para todo propósito útil para mí o para mis congéneres, muerto; por ende, todo lo que pueda escribir de ahora en adelante lo llamo memoria póstuma". ${ }^{84}$ Adams continuó su "memoria póstuma" hasta el 4 de febrero de $1848-19$ días antes de su muerte. ${ }^{85}$

Relevado de todos sus deberes de comités excepto el de la Biblioteca del Congreso, Adams siguió asistiendo a las sesiones del Congreso. Demasiado débil para hablar, votó en todas las resolución consideradas por el pleno de la Cámara de Representantes. Estaba en su curul el lunes 21 de febrero de 1848, el mismo día en que el presidente Polk recibió el Tratado de Guadalupe. El orador estaba anunciando los votos a favor y en contra de considerar las resoluciones para "presentar el agradecimiento del Congreso y condecoraciones a varios generales por acciones dignas en las campañas de 1847". Adams respondió con un claro y enfático "no" a la resolución. Fue su última palabra en la sala del Congreso.

Un reportero abolicionista estaba observando a Adams, quien intentaba levantarse, con las sienes enrojecidas, cuando se desplomó en brazos de David Fisher de Ohio, que ocupaba el asiento contiguo. ${ }^{86}$ Con la noticia de su derrumbe de inmediato se detuvieron las deliberaciones en la Cámara de Diputados, el Senado y la Corte Suprema. Adams fue recostado en un sofá y cargado hacia la oficina del orador, donde recobró la conciencia breve-

${ }^{84}$ Ibid., p. 279.

${ }^{85}$ Ibid., p. 271.

${ }^{86}$ Relatado por H. B. Stanton, para el Boston Emancipator and Republican, 21 de febrero de 1848 . Citado en ibid., p. 535. mente y llamó a Henry Clay, "quien entró y sollozando tomó su mano y luego partió" ${ }^{87}$ Adams murió el 23 de febrero de 1848 , un día después de que el Senado aprobó un tratado de paz con México que cedió casi 1500000 kilómetros cuadrados, un área más grande que España, Francia e Italia juntas, a Estados Unidos. ${ }^{88}$ Doce años después, la república americana sería devorada en la guerra fratricida que John Quincy Adams predijo y ocasionaría la toma de las provincias norteñas de México.

Durante la década de 1810, buscando ampliar la autosuficiencia económica y la extensión territorial de Estados Unidos, Adams había desestimado el potencial cívico de México y estaba ansioso por adquirir Texas y otros territorios mexicanos. Como un ardiente nacionalista, estaba cegado por la ilusión de que Estados Unidos, simplemente en virtud de su existencia, evitaría perpetuar barbaridades como la esclavitud y la conquista que había corrompido a los imperios del "viejo mundo". Las ilusiones de Adams se rompieron cuando lo derrotó Andrew Jackson en las elecciones de 1828. Al oponerse a la expansión de la esclavitud -y a la posibilidad de que la república se convirtiera en un imperio conquistador-, Adams se vio obligado, a pesar de sí mismo, a defender la integridad de México. Como opositor a la expansión jacksoniana, Adams imitó a sus paisanos que habían defendido la independencia mexicana durante la década de 1810: los estadunidenses tenían que defender la soberanía y el potencial cívico de México, o bien traicionar sus ideales cívicos básicos. Estados Unidos po-

${ }^{87}$ Ibid., p. 536.

${ }^{88}$ Miller, Mexico, 1985, p. 229. 
día conquistar territorios mexicanos, pero sólo violando los ideales cívicos que imbuían su existencia nacional de dignidad y significado. Esta es la verdad que se dramatiza de manera tan vívida en la transformación de la actitud de John Quincy Adams hacia México en el transcurso de su larga carrera política.

\section{HEMEROGRAFÍA}

Genius of Universal Emancipation.

Niles Register.

Weekly Register.

\section{BIBLIOGRAFÍA}

-Adams, Charles Francis, Memoirs of Jobn Quincy Adams, J. B. Lippincott and Co., Filadelfia, 1874-1877.

-Adams, John, The Selected Writings of John and Jobn Quincy Adams, Adrienne Koch y William Peden (eds.), Alfred A. Knopf, Nueva York, 1946.

-Adams, John Quincy, "Oration Delivered at Plymouth at the Anniversary Commemoration of the First Landing of our Ancestors at that Place", Russell y Cutler, Boston, 1802. , "Address Delivered on the Occasion of Reading The Declaration of Independenc Fourth of July, 1821", Davis \& Force, Washington, 1821.

- "Speech of John Quincy Adams on the Joint Resolution for Distributing Rations to the Distressed Fugitives from Indian Hostilities in the States of Alabama and Georgia", National Intelligencer Office, Washington, D. C., 1836.

-, Jobn Quincy Adams and American Continental Empire, Walter La Feber (comp.), Quadrangle Books, Chicago, 1965.
- Memoirs of John Quincy Adams, Charles Francis Adams (ed.), Books for Libraries Press, Freeport, Nueva York, 1969, t. 5, pp. 9-12. -Ammon, Harry, James Monroe: The Quest for National ldentity, McGraw-Hill Book Company, Nueva York, 1971.

-Bemis, Samuel, John Quincy Adams and the Union, Alfred A. Knopf, Nueva York, 1965.

-Benton, Thomas Hart, Thirty Years' View, D. Appleton \& Co., Nueva York, 1854, t. 1.

-Brack, Gene M., Mexico Views Manifest Destiny, 1821-1846, University of New Mexico Press, Albuquerque, 1975.

-Brackenridge, H. M., "Views of Louisiana" en Reuben Gold Thwaites (comp.), Early W/estern Travels, 1748-1845, The Arthur Clark Company, Cleveland, Ohio, 1904, t. 6.

-Clay, Henry, The Works of Henry Clay, Calvin Colton (comp.), The Knickerbocker Press, G. P. Putnam's Sons, Nueva York, 1904, tt. 1, 6, p. 245.

-Dillon, Merton L., "Benjamin Lundy in Texas", Soutbwestern Historical Quarterly, núm. 63, 1959, p. 48.

-Freehling, William, Road to Disunion, Oxford University Press, Nueva York, 1990, p. 23.

-Graebner, Norman, Empire on the Pacific: A Study in American Continental Expansion, The Ronald Presss Co., Nueva York, 1955.

-Hecht, Marie B., John Quincy Adams: A Personal History of an Independent Man, The Macmillan Co., Nueva York, 1972.

-Hietala, Thomas R., Manifest Design: Anxious Aggrandizement in Late Jacksonian America, Cornell University Press, Ithaca, 1985.

-Jefferson, Thomas, "Observations of Demeunier's Manuscript" [1786], en Julian P. Boycl et al. (comps.), Jefferson Papers, Princeton University Press, Princeton, 1950, t. 10, p. 310.

-Kraditor, Aileen S., Means and Ends in American Abolitionism: Garrison and his Criticas on Strategy and Tactics, 1834-1850, Pantheon Books, Nueva York, 1967. 
-Lewis Jr., James E., The American Union and the Problem of Neigbborbood, 1783-1829, The University of North Carolina Press, Chapel Hill, 1998.

- John Quincy Adams: Policymaker for the Union, Scholarly Resources, Wilmington, Del., 2001.

-Lundy, Benjamin, The War in Texas, W. D. Parrish, Filadelfia, 1836.

- The Life, Travels and Opinions of Benjamin Lundy, Including His Journeys to Texas and Mexico, with a Sketch of Contemporary Events, and a Notice of the Revolution in Haiti, Thomas Earle (comp.), W. D. Parrish, Filadelfia, 1847.

-Madison, James, "Ten: The Utility of the Union as a Safeguard Against Domestic Faction and Insurrection", The Federalist Papers, The New American Library, Nueva York, 1961.

-Merk, Frederick, Slavery and the Annexation of Texas, Alfred A. Knopf, Nueva York, 1972.

-Miller, Robert, Mexico: a Hisotry, University of Oklahoma Press, Norman, 1985.

-Miller, William, Arguing About Slavery, Alfred A. Knopf, Nueva York, 1996.

-Monroe, James, Writings of James Monroe, Stanislaus Murray Hamilton (comp.), Putnam's Sons, Nueva York, 1902, t. 6.
-Nagel, Paul C., John Quincy Adams: a Public Life, a Private Life, Alfred A. Knopf, Nueva York, 1997.

-Pike, Zebulon, The Expeditions of Zebulon Montgomery Pike, Elliott Coues (comp.), F. P. Harper, Nueva York, 1895, t. 3.

-Rather, Ethel, Recognition of the Republic of Texas by the United States, University of Texas, Austin, Texas, 1911.

-Remini, Robert V., Jobn Quincy Adams, Times Books, Nueva York, 2002.

-Richards, Leonard L., The Life and Times of Congressman Jobn Quincy Adams, Oxford University Press, Nueva York, 1986.

-Sedgwick, Theodore, Thoughts on the Proposed Annexation of Texas to the United States, D. Fanshaw, Nueva York, 1844.

-Smith, Justin H., The Annexation of Texas, The Baker and Taylor, Nueva York, 1911.

-The Legion of Liberty! and Force of Truth, Containing the Thoughts, Words and Deeds of Some Prominent Apostles, Champions and Martyrs, American Abolitionist Society, 2a. ed., Nueva York, 1843.

-Watts, Steven, The Republic Reborn: War and Making of Liberal America, 1790-1820, The Johns Hopkins University Press, Baltimore, 1987. 